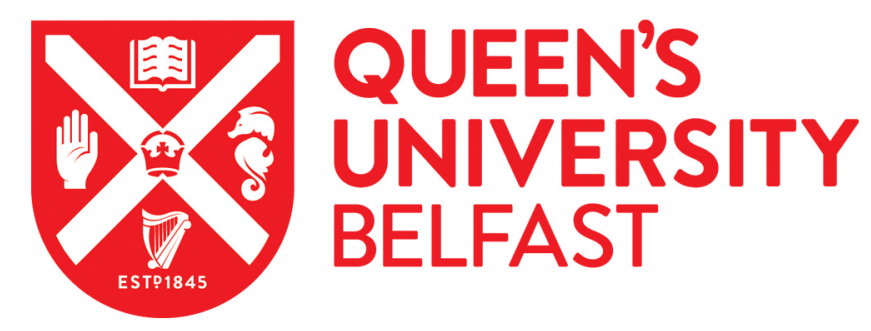

\title{
Regulatory own goals: the unintended consequences of economic regulation in professional football
}

Gallagher, R., \& Quinn, B. (2019). Regulatory own goals: the unintended consequences of economic regulation in professional football. European Sports Management Quarterly.

https://doi.org/10.1080/16184742.2019.1588344

\section{Published in:}

European Sports Management Quarterly

\section{Document Version:}

Peer reviewed version

Queen's University Belfast - Research Portal:

Link to publication record in Queen's University Belfast Research Portal

\section{Publisher rights}

(C) 2019 European Association for Sport Management.

This work is made available online in accordance with the publisher's policies. Please refer to any applicable terms of use of the publisher.

\section{General rights}

Copyright for the publications made accessible via the Queen's University Belfast Research Portal is retained by the author(s) and / or other copyright owners and it is a condition of accessing these publications that users recognise and abide by the legal requirements associated with these rights.

Take down policy

The Research Portal is Queen's institutional repository that provides access to Queen's research output. Every effort has been made to ensure that content in the Research Portal does not infringe any person's rights, or applicable UK laws. If you discover content in the Research Portal that you believe breaches copyright or violates any law, please contact openaccess@qub.ac.uk. 


\title{
Regulatory Own Goals: The Unintended Consequences of Economic Regulation in Professional Football
}

\author{
RONAN GALLAGHER $\uparrow$ and BARRY QUINN $\$$ \\ † University of Edinburgh Business School, EH8 9JS, Edinburgh, UK \\ (email: ronan.gallagher@ed.ac.uk) \\ † Queens University Management School, BT7 1NN, Belfast, UK \\ (email:b.quinn@qub.ac.uk)
}

\begin{abstract}
Research question: In 2010, the governing body of European football, UEFA, approved “Financial Fair Play” regulations. Designed to encourage financial discipline, promote stability and foster competitive balance, they focus on a financial breakeven constraint. We analyse the impact of such constraints on the joint sporting and financial efficiency of English football clubs.
\end{abstract}

Research methods: The simultaneous production of both sporting and financial outputs are modelled using stochastic, non-parametric efficiency analysis. The sample is an unbalanced panel representing 60 clubs spanning the 2003/2004 to 2016/2017 seasons.

Results and Findings: The Financial Fair Play breakeven regulation reduces average club efficiency, raises the relative importance of financial goals (capturing revenue share) whilst lowering the relative importance of sporting goals (capturing point share). The efficiency costs of regulation are not borne equally by clubs.

Implications: Breakeven regulations reduce the joint sporting and financial efficiency of regulated clubs, with the efficiency loss positively related to the severity of the breakeven constraint. The Financial Fair Play regulations further entrench the financial and sporting power of elite clubs and potentially undermine league competitive intensity by shifting the relative focus of clubs away from sporting productivity toward financial productivity. 


\section{Keywords}

Financial Fair Play, Regulation, Efficiency Analysis, Unintended Consequences, Professional Football

The authors would like to thank Thomas Peeters, Stefan Szymanski, Timo Kuosmanen, Andrew Johnson, John Turner, John Wilson and Paul Schure and two anonymous reviewers for helpful comments during the development of this paper. We thank Ashleigh Neill for research assistance. In addition, we would like to thank the Sports Business Group at Deloitte LLP for access to club financial data. All errors and omissions are our own.

\section{Introduction}

In 2010, against a backdrop of widespread financial instability in professional football, UEFA (Union of European Football Associations) announced a revised regulatory framework for clubs in its member nations. Subsequently adapted by domestic league competitions, 'Financial Fair Play' (FFP) regulations centre on a financial breakeven constraint. Loss making clubs must ensure that they do not breach the regular FFP loss threshold. If they do, they may up to a maximum allowable loss; cover the excess by owner equity injection. Breaching the regular loss level without owner equity injection or breaching the maximum allowable loss results in censures, which may be financial, sporting (prohibition from competing in European club competitions) or a combination of both.

The regulations have been divisive. Proponents argue that the constraint enforces financial discipline, incentivises diversification of revenue streams and engenders competitive balance. Opponents argue that it is an inefficient means of moderating expenditure, reduces investment in the sport, potentially violates European labour and competition law and entrenches the financial and sporting standing of Europe's elite clubs.

This study investigates the impact of FFP's breakeven constraint on the joint financial and sporting efficiency of English football clubs. The sample is drawn from the top two tiers of English professional football - the Premier League and the Championship from 2003 to 
2017. We analyse the trade-off between economic and sporting goals and detail how aspects of the operating environment (such as competing in European competitions, promotion, relegation, stadium utilisation, commercial independence and manager turnover) impact relative club efficiency.

The results suggest that breakeven constraints reduce average club efficiency, raise the relative importance of financial goals (i.e. capturing a larger share of the total revenue produced by all clubs in a given league tier, in a given season) whilst lowering the relative importance of sporting goals (i.e. capturing a larger share of the total points earned by all clubs in a given league tier, in a given season). Each trend is exacerbated by the degree of regulatory severity. The decline in efficiency is less marked for those clubs which are viewed as elite and thus politically powerful.

It is argued that pushing for promotion and competing in the Champions League significantly reduce efficiency and more-so as the degree of regulatory severity increases. Clubs which are less reliant on central distributions (from the Premier League, Championship and UEFA) are significantly more efficient and the importance of this commercial independence increases as the breakeven regulations tighten. Clubs which have higher rates of stadium utilisation (i.e. higher average attendances as a proportion of stadium capacity) are more efficient. Managerial change is associated with a contemporaneous decline in efficiency, albeit of marginal statistical significance. In the season post change, clubs are significantly more efficient, with the efficiency gains largely increasing with regulatory severity.

The work contributes to the literature on the economics of regulation. The results are suggestive of private interest theory of regulation and the related concept of regulatory capture (Peltzman, 1976; Posner, 1974; Stigler, 1971). FFP's breakeven constraint serves to widen the efficiency gap between those at the top and bottom of the efficiency distribution. The efficiency costs of regulation are not borne equally by clubs. This serves to further entrench the financial 
and competitive positions of the elite and politically powerful clubs (Szymanski, 2014), many of whom established commercial and sporting dynasties in the pre FFP era.

The study also contributes to the literature on the unintended consequences ${ }^{1}$ of regulation (Averch \& Johnson, 1962; Merton, 1936; Spatt, 2006; Stigler, 1971). The findings suggest that the FFP regulations on-balance reduce the average club's efficiency whilst simultaneously shifting the relative importance of priorities from sporting (capturing point share) to financial (capturing revenue share). Although the increased financial focus may be viewed as an intended goal, the extent of the decline in the relative importance of sporting performance is unintended and may lead to an overall decline in the sporting quality of the league ${ }^{2}$.

This study also contributes to the literature on professional club management (by clubs and regulators) and has profound implications for those who administer and operate under break-even based regulatory regimes. It is argued that if a club strives to be efficient, the greater the degree of regulatory severity the more the club should devote resources to capturing revenue share over point share. It is suggested that time and resource would be more productively employed in developing new club specific commercial deals rather than investing in playing talent. It is argued that club efficiency benefits from more intensive stadium capacity utilisation, a suggestion more relevant to Championship clubs who have greater degrees of

\footnotetext{
${ }^{1}$ These unintended consequences can stem from many sources: human error; the inability to model complex interactions amongst regulated actors; the 'imperious immediacy' of a single regulatory interest to the detriment of all others.

${ }^{2}$ Akerlof (1976) notes that competitive sporting leagues have a 'rat race' structure where teams compete for mutually exclusive ranking. By placing budget constraints on clubs, the regulations reduce the market-clearing price of playing talent (Budzinski (2014) and Szymanski (2014)). Given the close link between playing talent and sporting production, budget constraints reduce the market clearing price of attaining a given league position. Wage constraints are not necessarily met by a reduction in the supply of football talent given its relative inelasticity to player wages. In the face of a relatively static pool of footballing talent, the primary channel for declines in sporting efficiency relate to declines in player productivity. If wage falls undermine player productivity significantly it is reasonable to assert that the quality of the competitive product should decline commensurately.
} 
capacity slack. It is noted that management change has the power to increase efficiency, but any discernible impact is detectable in the season post managerial change.

\section{The FFP Regulations}

The original guidance on UEFA's FFP regulations was published in 2010 with sanctions for noncompliance effective from the end of the 2013/14 season. The break-even requirement states that clubs have an allowable deviation (loss) of $€ 5 \mathrm{~m}$ from break-even assessed over a three-year rolling window. Subject to owner equity injections covering the excess loss, clubs were permitted to breach the $€ 5 \mathrm{~m}$ limit up to a maximum allowable loss level of $€ 45 \mathrm{~m}$. This was subsequently revised down to $€ 30 \mathrm{~m}$ in the 2015/16 season. As well as the break-even requirement a second condition known as the payables requirement prohibits clubs from having overdue creditors.

For FFP, break-even is defined as relevant income minus relevant expenditure. Relevant income captures the primary sources of footballing revenue: gate receipts, broadcasting rights, sponsorship, advertising, other commercial activities plus profits from disposal of player registrations. The relevant expenditure category includes cost of sales, employee benefit expenses and other operating expenses, plus either amortisation or costs of acquiring player registrations, finance costs and dividends. Relevant expenses exclude items such as expenditure on youth development activities, women's football (from 2015), expenditure on community development and finance costs directly attributable to the construction of tangible fixed assets.

In February 2013 at the Premier League shareholders meeting, member clubs agreed a regulatory framework ${ }^{3}$ similar in structure to UEFA's FFP regulations. Firstly, clubs were

\footnotetext{
${ }^{3}$ By March 2014, clubs were required to submit financial information in compliance with the updated regulatory code. The first break-even decisions were taken at the end of the first three-season year rolling window (in Summer 2016).
} 
allowed to deviate from break-even (i.e. lose) $£ 15 \mathrm{~m}$ over a three year rolling window. Losses in excess of this amount up to a total loss of $£ 105 \mathrm{~m}$ were permitted subject to owner equity injection of the excess. In addition, to control for short run cost increases, clubs are limited in raising wage bills (inclusive of player image rights) by $£ 4 m$ per season unless they can demonstrate contemporaneous revenue uplift (excluding central distributions from the Premier League itself) to cover the balance.

In the Championship (the second tier of English professional football), beginning in $2012 / 13$ clubs faced an acceptable deviation from break-even of $£ 3 m$ per year, or up to $£ 8 m$ if the excess was covered by owner equity injection. In the 2015/16 season the regulation further harmonised with the UEFA and Premier League by assessing over a three year rolling period rather than annually. Over this window clubs are permitted to lose $£ 15 \mathrm{~m}$ without a mandatory equity injection or up to $£ 39 \mathrm{~m}$ if equity is injected to cover the excess loss over $£ 15 \mathrm{~m}^{4}$. To summarise European and domestic FFP thresholds are currently set at the following levels:

$$
<<<\text { Table } 1 \text { Here }>>>
$$

\section{Literature Review: Analysis of FFP Regulations}

Budzinski (2018) argues that agency problems can create incentives whereby regulators pursue goals other than those in direct benefit of all teams. Given that FFP regulations are a major extension of power of UEFA, the Premier League and the Football League, a spirited debate has arisen on their intent and structure.

Proponents cite several key reasons for their necessity. Müller, Lammert, and Hovemann (2012) note that most professional leagues are structured in a 'rat race' framework where clubs compete for mutually exclusive ranking. In the pursuit of perceived 'jackpot'

\footnotetext{
${ }^{4}$ Given that losses are calculated on the basis of three year averages, clubs that have been relegated from the Premier League during the time period can use the maximum allowable Premier League loss $(£ 105 \mathrm{~m} / 3=£ 35 \mathrm{~m}$ a season including owner equity injection) for those seasons in which they played in the top flight.
} 
outcomes they overinvest to the detriment of profitability. Franck (2014) notes that due to systematic overinvestment many clubs are de-facto insolvent, kept afloat only by cash injections from wealthy benefactors. This creates a soft budget constraint, suboptimal management behaviour and inefficient resource allocation. Franck \& Lang (2013) argue that such clubs undertake riskier investments and are inherently more unstable. Budzinski and Muller (2013) note that some prominent clubs in the largest European markets could be considered 'too prominent to fail'. Franck (2014) argues that public funding may be required to bailout clubs of this nature. To the extent that FFP regulations harden club budget constraints, proponents argue that they reduce the capacity for overinvestment, lower the likelihood of club financial distress and help mitigate moral hazard inherent with being 'too prominent to fail'.

Franck (2014) argues that imposition of budget constraints promote efficient and effective management practice leading to a rise in the average level of (sporting and financial) management quality in the league. Müller et al. (2012) note that FFP effectively limits the capacity for "financial doping" by wealthy benefactors to the benefit of league integrity which is considered a bedrock of sporting competition.

Many commentators have criticised the structure and underlying intent of the FFP regulations. Several authors (e,g. Maxcy (2014), Szymanski (2014) and Sass (2016)) note that FFP effectively creates a barrier to entry for potential owners. This serves to maintain the status quo i.e. the competitive positions of those clubs whose dynasties were established in the pre-FFP era.

Szymanski (2014) argues that FFP may serve to reduce investment in the European game to the detriment of fan experience. It is noted that the size of commercial deals, attendance and global attention on the European game have increasingly significantly over a period in which financial and competitive inequality at clubs has risen. Moreover, the assertion that 
wealthy benefactors are an unsustainable funding source for clubs is challenged on the basis that the number and variety of benefactors continues to rise over time. Several critics document that FFP regulations in their current form transfer economic rents from players to club owners. Revenue related caps on player expenditure reduce the market-clearing price of playing talent. The beneficiaries are owners, most prominently those of the highest status clubs with the largest wage bills. Several researchers question whether this transfer of rents is in adherence with EU law. Budzinski (2014) and Szymanski (2014) point to the inequality engendered by the FFP regulations and a recent court challenge by player agents on the grounds of restriction on investments of owners, deflation of player salaries and fossilisation of market structure.

FFP monitoring costs are identified as a significant concern (Vöpel, 2011). The FFP regulations class certain forms of income and expenditure as "relevant" in the breakeven calculation. Classification shifting, and creative accounting have the potential to undermine the goals of FFP (Budzinski, 2014). The monitoring of related party transactions require detailed scrutiny to assess whether commercial deals are signed at "fair market value". If the FFP regulations are to be viewed as credible, regulatory arbitrage schemes should be monitored closely, and sanctions applied judiciously. Müller et al. (2012) raise some concerns in this regard and claim that sanctions for violation of FFP lack ex-ante clarity thus undermining their credibility.

\section{Empirical Methodology}

Team performance is measured relative to an efficient production frontier. In the context of English football, efficiency analysis has been applied using two competing paradigms - Data Envelopment Analysis (DEA) (Barros \& Leach, 2006b; Guzmán \& Morrow, 2007; Haas, 2003) and Stochastic Frontier Analysis (SFA) (Barros \& Garcia-del-Barrio, 2008; Barros \& Leach, 2007; Carmichael, McHale, \& Thomas, 2011; Dawson, Dobson, \& Gerrard, 2000b). DEA sacrifices the modelling of noise for the ability to impose axiomatic properties and estimate the 
frontier non-parametrically. SFA sacrifices the imposing of axiomatic properties for the benefit of modelling inefficiency and noise (Johnson, Kuosmanen \& Sasstamoinen, 2015). In this study the innovative StoNEZD (Kuosmanen \& Johnson, 2009; Johnson et al., 2015) approach is used to estimate club efficiency. It combines desirable aspects of both DEA and SFA: no functional form need be specified ex-ante, yet it also facilitates the modelling of noise via semi non-parametric estimation.

\section{The Model}

Neoclassical theories of the firm are inadequate for understanding the economic behaviour of football teams where success is measured in both sporting and financial terms. Evidence is mixed regarding the relative importance of these dimensions. Garcia-del-Barrio and Szymanski (2009) argue that football can be characterised as win maximising, subject to a zero profit budget constraint ${ }^{5}$. Carmichael and Thomas (2014) argue that top flight teams primarily strive for league survival and then a dominant domestic league position. The former enables continuing receipt of significant broadcasting revenue, while the latter provides access to lucrative continental club competition revenue. Peeters and Szymanski (2014) opine that football is a heterogeneous mix of wealth and win maximising motives.

Football teams compete for on-field success but can cooperate for off-field (financial) success (Garcia-del-Barrio \& Szymanski, 2009), with competition characterising on-field success as a zero-sum game. Tullock (1980) captures these unique aspects of production in sport using a model where playing success is driven by the relative share of resources employed. Team production is modelled as:

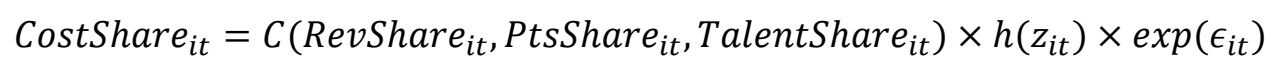

\footnotetext{
${ }^{5}$ They suggest this finding may be an artefact of the period of investigation, where intense competition for broadcasting and media exposure meant clubs where achieving a dominant sporting position to achieve higher profits in the longer term.
} 
This cost function defines the minimum cost for providing outputs Revenue Share (RevShareit), and Points Share (PtsShareit). Cost Share it is the total variable cost of club i in season t. C(.) is non-parametric, $\mathrm{h}($.$) is parametric, and \varepsilon_{\mathrm{it}}=\mathrm{u}_{\mathrm{it}}+\mathrm{v}_{\mathrm{it}}$, is a composite error term that combines inefficiency $\left(\mathrm{u}_{\mathrm{it}}\right)$ and noise $\left(\mathrm{V}_{\mathrm{it}}\right)$. The model is intertemporal as the function $\mathrm{C}($.$) is applied over$ all seasons in the panel (Tulkens \& Vanden Eeckaut, 1995). The Zit vector captures the operating environment of the club and is also used to impose hypothetical retrospective FFP regulatory conditions.

Importantly, no functional form is imposed on $\mathrm{C}($.$) ; rather a more relaxed set of$ axiomatic assumptions are used which assume $\mathrm{C}$ is monotonic, convex, and exhibits constant returns to scale ${ }^{6}$. Equation 2 is estimated using the innovative StoNEZD approach which solves:

$$
\min _{\gamma \beta \theta \tilde{\epsilon}} \sum_{i=1}^{I} \sum_{t=1}^{T} \tilde{\epsilon}_{i t}^{2}
$$

subject to:

$$
\begin{gathered}
\ln \left(\text { CostShare }_{i t}\right)=\ln \left(\alpha_{i t}+\beta_{1 i t} \text { RevShare }_{i t}+\beta_{2 i t} \text { PtsShare }_{i t}+\theta_{i t} \text { TalentShare }_{i t}\right)+\gamma z_{i t}+\tilde{\epsilon}_{i t} \\
\alpha_{i t}+\beta_{1 i t} \text { RevShare }_{i t}+\beta_{2 i t} \text { PtsShare }_{i t}+\theta_{\text {it }} \text { TalentShare }_{i t} \geq \alpha_{i t}+\beta_{1 j k} \text { RevShare }_{i t}+ \\
\beta_{2 j k} \text { PtsShare }_{i t}+\theta_{j k} \text { TalentShare }_{i t} \\
\beta_{1 i t}, \beta_{2 i t}, \theta_{i t} \geq 0 \\
i=(1, \ldots, I) t=(1, \ldots, T) j=(1, \ldots, I), k=(1, \ldots, T)
\end{gathered}
$$

This is a least squares regression written as a nonlinear mathematical programming problem. The first equality allows for the shadow price estimates ( $\left.\beta_{1 \mathrm{it}}, \beta_{2 \mathrm{it}}, \theta_{\mathrm{it}}\right)$ to vary across both club and season. In duality theory it has been well established that the cost function is an equally valid production technology representation as the conventional production function, or

\footnotetext{
${ }^{6}$ This assumption is tested, and results are available upon request from the authors.
} 
a distance function (e,g., Fare and Primont (2012)). Importantly, the use of a cost function does not necessarily require or imply cost minimisation. In fact, the above duality theory requires no a priori behavioural assumption thus allowing the model to fully capture the heterogeneous mix of team performance objectives (Eskelinen \& Kuosmanen, 2013).

A further challenge in modelling team performance is the feedback loop between revenue, player spending and sporting success (Garcia-del-Barrio \& Szymanski, 2009; Leach \& Szymanski, 2015; Szymanski \& Smith, 1997). Hall, Szymanski, and Zimbalist (2002) argue causation runs from wages to success in English Premier teams. In contrast, Dobson and Goddard (1998) find lagged revenue causes current performance for Football League teams, with a more pronounced effect for smaller clubs. Peeters and Szymanski (2014) control for unobserved player productivity using both an instrumental variable and a club specific fixed effect approach in their parametric contest function. The model can accommodate these endogeneity issues and provide valid estimates. Specifically, the panel data solution for the simultaneity problem in production modelling (Mundlak, 1961; Mundlak \& Hoch, 1965) is extended by providing nonparametric time-varying club specific effects $\alpha_{i t}{ }^{7}$. These 'catch all' estimates absorb unobserved productivity and, if the feedback effect from wages to success has a constant variation across club's and seasons, capture the unobservable nature of this feedback.

\section{Modelling the Operating Environment}

The $\mathrm{z}$ vector captures elements of cross-club heterogeneity and temporal changes over the sample. The StoNEZD estimator allows for simultaneous estimation of efficiency scores and their decomposition as a function of environmental variables. In doing so it controls for correlations between environmental variables and efficiency model outcomes (Johnson \& Kuosmanen, 2012).

\footnotetext{
${ }^{7}$ A variable returns to scale specification is used to estimate these effects.
} 
The $\mathrm{z}$ vector includes dummy variables which control for Champions League and Europa league qualification. The implications of promotion and relegation ${ }^{8}$ are modelled using two dummies; Promotion Push identifies a club in the year immediately preceding promotion to the Premier League, Relegated identifies a club relegated from the Premier League in the prior season. We examine how manager turnover impacts efficiency ${ }^{9}$. A Managerial Change dummy identifies those seasons where there was at least one manager turnover event. A lag of this dummy is included to capture the inter-temporal impact of management turnover. Stadium Utilisation is measured by calculating the average attendance as a proportion of stadium capacity each season. Against a backdrop of higher ticket prices and increased broadcast of games, most clubs sampled have spare attendance capacity with this slack much more notable in the Championship. If the demand for tickets is price elastic, ticket price cuts have the capacity to simultaneously increase attendance and raise ticket revenue. This has the potential to raise financial efficiency by utilising existing infrastructure more intensively. If greater home fan attendance has a positive impact upon player productivity it may also lead to more efficient sporting performance of the home team. Each club's Commercial Independence is measured as the proportion of revenues that come from non-central sources (i.e. those revenues that are not derived from central distributions from UEFA, the Premier League and the Championship). A set of season-tier dummies are included to capture unobservable temporal effects.

Akin to the literature on counterfactual economic analysis of regulation (Glass, McKillop, \& Rasaratnam, 2010) the hypothetical financial regulation conditions are imposed within the z vector. Following Peeters and Szymanski (2014) FFP break-even constraints are

\footnotetext{
${ }^{8}$ Goddard (2014) contends the opening of competition through the promotion and relegation system creates large disparities between the operating environments of the two tiers. He argues this system has a detrimental effect on profitability, owing to the pervasive tendency to overspend to achieve promotion or avoid relegation.

${ }_{9}^{9}$ González-Gómez, Picazo-Tadeo, and García-Rubio (2011) demonstrate that clubs who sack managers midseason have lower sporting efficiency in the lead up to the sacking, however replacement improves sporting efficiency thereafter. Bridgewater (2009) suggests that the positive impact of manager appointment is short-lived and is associated with a longer term mean reversion after an initial 'honeymoon' period. This is echoed by Hughes, Hughes, Mellahi, and Guermat (2010).
} 
imposed at the $£ 15 \mathrm{~m}, £ 10 \mathrm{~m}, £ 5 \mathrm{~m}$ and $£ 5 \mathrm{~m}$ over three consecutive seasons thresholds. Each threshold is calibrated using pre-tax profits in each season, and dummy variables take the value of one if the club's pre-tax losses exceed the threshold value and zero otherwise.

The StoNEZD estimator is a form of regression and therefore marginal effects can be extracted. Specifically, the equality constraint from equation 2 can be rewritten:

$$
\begin{gathered}
\gamma z_{i t}+\tilde{\epsilon}_{i t}=\ln \left(\text { CostShare }_{i t}\right)-\ln \left(\alpha_{i t}+\beta_{1 i t} \text { RevShare }_{i t}+\beta_{2 i t} \text { PtsShare }_{i t}+\theta_{i t} \text { TalentShare }_{i t}\right) \\
\gamma z_{i t}+\tilde{\epsilon}_{i t}=\ln \left(\frac{\text { CostShare }_{i t}}{\alpha_{i t}+\beta_{1 i t} \text { RevShare }_{i t}+\beta_{2 i t} \text { PtsShare }_{i t}+\theta_{i t} \text { TalentShare }_{i t}}\right)
\end{gathered}
$$

where the right-hand side is the log of cost inefficiency. Thus, the coefficient estimates for the $\mathrm{z}$ variables can be interpreted as the marginal effects of the $\mathrm{z}$ variables on the $\log$ of cost inefficiency.

To attach economic meaning to these marginal effects in the log-linear model the estimates must first be exponentiated. Furthermore, if the $\mathrm{z}$ variable is binary the exponentiated estimate corresponds to the ratio of the expected geometric means of the unlogged outcome variable for the two coded groups. This can be interpreted as the percentage difference in the geometric mean between groups.

\section{Data and Shadow Price Testing}

Financial statement data is sourced from the Deloitte Annual Reviews of Football Finance. This data is extracted from the annual financial statements of the legal entity registered in the UK which is at, or closest to, the top of the club ownership structure. It is adjusted to provide a clearer picture of the football business by extracting, where available, financial activities or 
significant capital transactions relating to non-football activities ${ }^{10}$. To clean the Deloitte data the following additions and amendments were made:

1. There are instances where Deloitte did not update a particular variable in a given year, instead incorrectly assuming stasis from the prior year. These are treated in the same manner as other missing data - to the maximum extent possible the correct values from the club's annual report are obtained from Companies House ${ }^{11}$.

2. Where a club had a non-standard reporting year, we extract the 12 month equivalent values (if reported) or otherwise rescale variables relating to accounting flows ${ }^{12}$ on a pro-rata basis.

Financial data is augmented with sporting data sourced from the Premier and Football League's websites. The full sample is an unbalanced panel representing 60 clubs spanning the 2003/2004 to $2016 / 2017$ seasons. In total, there are 594 club-season observations.

$$
<<<\text { Table } 2 \text { Here }>>>
$$

\section{Inputs and Outputs}

The main input factor, CostShare, is the variable cost share of the club where cost is measured as the total of salaries, amortisation of player registrations ${ }^{13}$ and match day expenses. Financial

\footnotetext{
${ }^{10}$ For example revenues relating to property development (e.g. Arsenal in 2013-14), travel agency (Chelsea in 2003-04) and sale of intellectual property to related parties (e.g. Manchester City in 2013-14) have been excluded where identifiable

${ }^{11}$ If data for a given club-year is unavailable from Companies House that club-year is excluded from the sample. In most cases non-filing clubs were under administration.

${ }^{12}$ Accounting stock variables are measured point in time and thus left unscaled.

${ }^{13}$ Accounting standards require the cost of acquiring a player's registration from another club to be capitalised on the balance sheet within intangible fixed assets. The capitalised amount is subsequently amortised over the player's contract.
} 
output is modelled as a club's revenue share ${ }^{14}$, RevShare. Revenue includes that generated from broadcasting, matchday and commercial activities. Broadcast revenue includes both domestic and international competitions capturing the financial success of playing in Europe. Matchday revenue is largely derived from gate receipts. Commercial revenue includes sponsorship, conference and catering, merchandising, licensing and other revenues. Sporting output is modelled as a club's domestic point share, PtsShare. When assessing team efficiency it is important to consider the variation in the talent available (Dawson, Dobson, \& Gerrard, 2000a), thus a variable input price, TalentShare, is included to capture the variation in playing talent available to management. This is measured as net book value share of the playing squad. Tables 3 presents a snapshot of the financial data over the sample period.

$$
<<<\text { Table } 3 \text { Here }>>>
$$

\section{A Note on Shadow Prices}

A key focus of the study is to understand the juxtaposition of a team's sporting and financial objectives, and how these objectives are affected by the imposition of various levels of regulatory stringency. These phenomena are investigated using shadow prices. Shadow prices are a 'virtual' or 'implicit' price (Färe \& Primont, 2012). They are the value of the marginal product faced by management based on the optimal choice of outputs and inputs which maximises utility (Murray, 1995). If the management's choices of input-output bundles are guided by rational economic objectives, these shadow prices reveal the underlying opportunity costs hidden from the researcher (Kuosmanen, Cherchye, \& Sipilainen, 2006). Importantly, this opportunity cost (economic price) definition can also be interpreted as marginal substitution (transformation) rates between inputs (outputs). Given that the model uses unit-

\footnotetext{
14 Considering revenue as an output is consistent with the resource-based theory of industrial efficiency (Wernerfelt, 1984; Barney, 1991; Rumelt, 1991). The flexibility of this theory has proven important in capturing the multidimensional objective of English professional football (Gerrard, 2005).
} 
free share variables this offers an intuitive appealing interpretation of the shadow price estimates as opportunity costs.

Equation 1 provides shadow price estimates. Given variables enter the model in share form, the shadow prices highlight the economic importance to a rational manager/owner of capturing market share in each variable and how this importance will change with increased financial regulation stringency.

\section{Results}

Given that the StoNZED approach to efficiency analysis is a sum of squares minimisation problem, a regression interpretation is appropriate. Using panel data, Eskelinen \& Kousmanen (2013) describe how a StoNZED consistent fixed effects model can be employed. In equation

4 the periodic deviation from the efficient frontier is measured as $\exp \left(-\hat{\varepsilon}_{i t}^{C N L S}\right)$, which captures both inefficiency and stochastic noise. Averaging this deviation over time leads to a measure of the inefficiency of a club over the sample period. Subsequently the most efficient club over the sample period can be identified and used as a benchmark for all others. The efficiency scores are normalised as a percentage of benchmark club efficiency to produce $\hat{E}_{i}$ efficiency scores bounded by $[0,1]$. A club with a score of 1 is operating on the efficient cost frontier. A club with a score less than 1 can improve their efficiency by producing the same share of outputs at a lower share of costs.

$$
\begin{gathered}
\bar{d}_{i}=\frac{1}{T} \sum_{t=1}^{T} \exp \left(-\hat{\varepsilon}_{i t}^{C N L S}\right) \\
\bar{d}_{i=\max }^{*}\left(\bar{d}_{i}\right) \\
\hat{E}_{i}=\bar{d}_{i} / \bar{d}_{i}^{*}
\end{gathered}
$$

$$
<<<\text { Table } 4 \text { Here }>>>
$$


Several noteworthy findings emerge in Table 4, which summarises efficiency by regulatory regime. Firstly, as the degree of break-even regulatory scrutiny becomes more severe the average club becomes relatively less efficient vis-à-vis the most efficient club. The cost efficiency gap between the mean (median) and most efficient club increases from around $6.8 \%(9.0 \%)$ under the no FFP model to $27.8 \%(37.9 \%)$ under the most stringent of regulatory regimes. The distribution of relative club cost efficiency (as measured by the standard deviation of efficiency scores) also widens significantly with increased levels of regulatory scrutiny.

We investigate how the efficiency cost of the breakeven regulations are distributed amongst regulated clubs. This facilitates examination of the hypothesis that the FFP regulations may in part have emerged because of rent seeking by politically powerful clubs in exerting control over the regulator. Doing so requires a classification of those clubs considered to be amongst the Premier Leagues elite and most powerful (domestically and internationally). It is noted that the FFP regulations were conceived by UEFA, a supranational regulatory entity. It is reasonable to assert that more successful clubs on the European stage hold more influence over UEFA. These clubs qualify for Europe's marquee club competition by finishing in the upper echelons of the Premier League so one could also argue that their political influence extends to the Premier League itself. Since the dawn of the Premier League era (in 1992), English representatives in the UEFA Champions League have consisted of a narrow and select group. Of the 84 instances of English club representation, 66 of those come from just four clubs: Manchester United, Arsenal, Chelsea and Liverpoo ${ }^{15}$. They have traditionally been labelled as English football's Big 4. One disruptor to this dominance can be noted in the sample. During the 2008-2009 season Manchester City were taken over by Sheikh Mansour

\footnotetext{
${ }^{15}$ All but Arsenal won the Champions League over that period. Of the 25 Premier League seasons since its inception, these four clubs have won the title 21 times.
} 
bin Zayed Al Nahyan. This was followed by unprecedented investment in the playing squad, management structure and stadium, transforming the sporting fortunes of the club. Consequently elite clubs are defined as the traditional Big 4 throughout the sample and Manchester City from 2008-2009 onwards. Hitherto this elite group is referred to as the Big $5^{16}$

Table 5 shows the change in mean efficiency for the Big 5 vis-a-vis the remaining clubs in the sample under the various regulatory formulations. The 'no FFP scenario' serves as a baseline. While both groups in general experience efficiency declines with heightened regulatory severity, the declines are more marked for clubs outside the Big 5. Under the most stringent regulatory formulation, the average efficiency loss for clubs outside the Big 5 is around four times that of those within. The efficiency loss gap widens as the regulations tighten. This suggests that despite reducing the overall efficiency of elite clubs, the regulations serve to entrench their financial and competitive positions vis-a-vis their domestic competitors. This is consistent with other research in the area (e.g. Peeters \& Szymanski 2014) and suggestive of the private interest rationale ${ }^{17}$ (Peltzman, 1976; Posner, 1974; Stigler, 1971) for the emergence of the FFP regulation. The entrenchment of the elite clubs may also be symptomatic of an environment where they are deemed "too-prominent-to-fail" (Budzinski, 2014). If regulatory bodies are subject to political interference they may be influenced by political interests to design regulation which insulates the elite (prominent) from competition. To the extent that

\footnotetext{
${ }^{16}$ In addition to their status as sporting elite, the Big 5 have revenue generation capacity that far outstripped their domestic competitors over the sample period. Their revenue accounted for over $49.81 \%$ of Premier League revenue in 2016/17.

${ }^{17}$ An alternative explanation asserts that the introduction of FFP regulations coincides with a period of heightened competitive intensity to avoid relegation from and gain promotion to the Premier League. If this is the case, lower levels of efficiency of clubs outside the elite may be driven by competitive dynamics rather than FFP. We proxy for competive intensity by calculating the Herfindahl index of points share amongst those clubs in the bottom 6 (and 10) places in the Premier League and those in the top 6 (and 10 places) in the Championship. We analyse the points required for survival in the Premier League, the gap between the first relegated and last surviving club, the point gap between automatic promotion and playoff places in the Championship and the point gap between the last club to qualify for the Championship playoffs and the first club to miss out. We find no statistical evidence of heightened sporting intensity in the pre and post FFP era. The results are available from the authors upon request.
} 
owners of elite clubs exert political influence, the private interest and "too prominent to fail" rationales may compound.

$<<<$ Table 5 Here $>>>$

The methodology allows us to investigate the efficiency dynamics via output shadow price estimates. Shadow prices can be interpreted as marginal costs or alternatively as relative importance measures in determining overall cost efficiency. Using either interpretation, allows analysis of the trade-offs clubs face in pursuing financial and sporting goals in an efficient manner under various regulatory regimes. Table 6 presents the mean and median of these shadow prices.

$<<<$ Table 6 Here $>>>$

Several noteworthy findings emerge. As break-even regulatory severity increases, the relative importance of capturing league revenue share increases. The mean (median) shadow price of revenue share rises from $0.391(0.422)$ to $0.511(0.537)$, meaning that each extra incremental percentage of league revenue share captured comes at an increasing cost of points share, from $0.391 \%(0.422 \%)$ in the non FFP regime to $0.511 \%(0.537 \%)$ in the most stringent regime. The mean (median) shadow price of points share falls from $0.342(0.333)$ to $0.221(0.201)$ meaning that each extra incremental percentage of points share captured comes at a decreasing cost of revenue share. Put simply as regulatory severity increases, revenue generation becomes more important for efficiency while points share (sporting success) becomes less important.

We test the significance of differences in shadow prices across regulatory regimes using the output ratio and standard approaches to testing group difference. The base case (no FFP) is compared to the various regulatory formulations. Table 7 summarizes the tests for differences in the relative importance (as measured by the ratio of shadow prices) of revenue versus 
sporting outputs. These results provide statistical evidence to corroborate the average differences observed in table 6.

$$
<<<\text { Table } 7 \text { Here }>>>
$$

Proponents of the FFP regulations may contend that this refocusing of football clubs towards revenue generation indicates that the break-even requirements of FFP are achieving their intended outcomes. However, we would urge caution in making such an assertion. The declining importance of sporting success in determining efficiency may in fact undermine the quality and competitive nature of English football. We argue that sporting and financial outcomes must be considered jointly in the spirit of the regulations. Having done so, the assertions are rather gloomy. The costs associated with FFP regulations appear to offset the gains, leaving the average club less efficient and the distribution of efficiency outcomes wider under more severe regulatory regimes.

The model permits an analysis of the drivers of inefficiency at the club level. Table 8 presents the results of this analysis using the simultaneous regression procedure ${ }^{18}$. Here the dependent variable, inefficiency, is modelled as a function of several explanatory variables which characterise the operating environment of a club. Table 8 presents the marginal effects of the environmental variables. As described in the methodology, the dummy variables have the intuitively appealing interpretation as the expected group difference in the geometric mean of a club's inefficiency.

$$
<<<\text { Table } 8 \text { Here }>>>
$$

\footnotetext{
${ }^{18}$ Importantly this regression procedure is not subject to the problems of the 2 stage DEA procedure (Simar \& Wilson, 2007) because the effects of the $\mathrm{z}$ variables are controlled for via simultaneous estimation of the frontier and the efficiency decomposing regression model.
} 
Pushing for promotion to the Premier League leads to an increase in inefficiency at the club level (in the region of $1 \%$ to $2 \%$ ). Moreover, as the degree of regulatory severity increases the efficiency implications of the promotion push loom larger. The results suggest that relegated clubs improve their efficiency in the year post relegation, however the wide variation in efficiency estimates for these clubs result in marginal statistical significance across most regulatory formulations.

Despite the perceived cash bounty of playing in the UEFA Champions League, clubs who do so are less cost efficient than those who do not. Playing in the Champions League is typically associated with an efficiency decline of around $4 \%$ to $5 \%$ under various levels of regulatory scrutiny. This is consistent with the observation that margins of the Champions League regulars are thinner. Assembling and servicing a squad capable of qualifying for the Champions League brings with its enormous cost implications. In addition, one could also assert that the imposition of playing Champions League football (where games are scheduled midweek) decreases levels of domestic performance lowering domestic sporting efficiency. Europa League competition has a much more muted impact as evidenced by either no or marginal statistical significance of this dummy variable across specification variants. This is perhaps unsurprising given that clubs competing in this competition have considerably lower expenditure on playing talent and salaries than those in the Champions League.

Clubs which are more commercially independent, i.e. those whose revenues are less reliant on central distributions from UEFA, the Premier League and the Championship, are significantly more efficient, and the impact of independence on efficiency increases with the severity of the regulatory regime. For a one standard deviation increase in commercial independence (corresponding to 21.20 percentage points), efficiency increases by between $0.46 \%$ and $0.73 \%$. This suggests that for efficiency striving clubs, operating under breakeven regimes, creating diverse commercial revenue streams is of paramount importance. 
Clubs which have greater stadium capacity utilisation rates are more efficient. For a one standard deviation increase in stadium capacity utilisation (corresponding to 15.80 percentage points), efficiency increases by between $0.31 \%$ and $0.37 \%$. It is noted that many clubs in the sample, particularly those in the Championship, have spare capacity. This suggests that ticket pricing, fan engagement and marketing initiatives aimed at increasing stadium utilisation are well founded in the pursuit of efficient operation.

Clubs which change their management have lower efficiency than those who don't in the season of change, however the significance of the relation is marginal. It is conjectured that the marginal significance is in part driven by declines in efficiency in the lead up to the change being partially offset by efficiency improvements in the 'honeymoon' period post change and prior to season end. In the season post manager change, clubs improve their efficiency by between $0.66 \%$ and $1.96 \%$. In general, the more severe the breakeven constraint, the greater the efficiency impact of prior season management change. The results assert that club executives who decide to replace management may benefit from an arrest in efficiency declines and subsequent improvement in efficiency thereafter.

Clubs defined as violators of the break-even condition under the various regulatory regimes are less cost efficient. As the degree of regulatory severity increases, so too does the relative inefficiency of violators compared to non-violators. Clubs which violate break-even requirements are typically between $5 \%$ and $7 \%$ less efficient than compliant peers. In all regulatory regimes, the marginal effects on the violation dummies are considerably higher than those relating to European club competition, promotion, relegation, commercial independence, stadium utility or management turnover.

\section{Conclusion}

This study analyses the impact of regulatory breakeven constraints (in the manner of UEFA and the Premier League's Financial Fair Play regulations) on the joint financial and sporting 
efficiency of English football clubs. The research has three main findings. Firstly, breakeven constraints reduce average club efficiency. Secondly, the reduction in club efficiency is not borne equally. Clubs that may be considered as politically elite ('the Big 5'), are handicapped less than their peers by the imposition of the regulation. Thirdly, breakeven constraints serve to raise the relative efficiency determining importance of financial goals (capturing revenue share) whilst lowering the relative importance of sporting goals (capturing point share). Each finding is heightened under tighter regulatory formulations.

Whilst one might conclude that the heightened importance of financial outcomes is a desired consequence of the regulations, it should be noted that financial efficiency gains are more than offset in sporting efficiency losses. As sporting efficiency captures the conversion of sporting input (i.e. playing talent) into sporting output (i.e. league point share), it is argued that any efficiency impairment reduces the quality of the sporting product. To the extent that this compromises fan experience it undermines one of the stated goals of the regulations namely to 'further promote and continuously improve the standard of all aspects of football'. We argue that this is an unintended consequence of the regulation.

Furthermore it is suggested that the regulations in their current form serve to protect the elite clubs who built their sporting and financial dynasties in the pre-FFP era. This supports the private interest theory of regulation which asserts that the regulatory mechanism is a means for the elite to extract economic rents from the non-elite. By opening up an efficiency gap between these two groups, this rent extraction may undermine the long-term league viability and may violate EU competition laws.

This study has implications for club management who operate under break-even based regulatory regimes. The greater the degree of regulatory severity, the more clubs will improve efficiency by allocating resources to capturing revenue share over point share. As central distributions by the Premier League and Championship are relatively even at the league level, 
the optimal strategy may thus be the pursuit of new sponsorship deals and commercial partnerships rather than investing in sporting talent. The findings also suggest that club efficiency benefits from higher stadium capacity utilisation. To that end ticket pricing, fan engagement and marketing strategies targeted at increasing attendances are valuable, and especially so in the Championship where capacity slack is more evident. It is noted that managerial turnover has a relatively muted and marginally significant impact on efficiency in the season of change. However, the findings suggest that in the season post change, overall efficiency improves. This implies that decisions to replace management may help arrest efficiency declines and thus be well founded from an efficiency perspective. We urge caution in chasing either promotion to the Premier League or Champions League qualification. While both come with a perceived cash bounty, the costs incurred in achieving them overwhelm any efficiency gains.

\section{Disclosure statement}

No potential conflict of interest was reported by the authors

\section{References}

Akerlof, G. (1976). The economics of caste and of the rat race and other woeful tales. The Quarterly Journal of Economics, 599-617.

Averch, H., \& Johnson, L. L. (1962). Behavior of the firm under regulatory constraint. The American Economic Review, 52, 1052-1069.

Barney, J. B. (1996). The Resource-Based Theory of the Firm. Organization Science, 7, 469469.

Barros, C. P., \& Garcia-del-Barrio, P. (2008). Efficiency measurement of the English football Premier League with a random frontier model. Economic Modelling, 25, 994-1002. 
Barros, C. P., Garcia-del-Barrio, P., \& Leach, S. (2009). Analysing the technical efficiency of the Spanish Football League First Division with a random frontier model. Applied Economics, 41, 3239-3247.

Barros, C. P., \& Leach, S. (2006a). Analyzing the performance of the English F.A. Premier League with an econometric frontier model. Journal of Sports Economics, 7, 391-407.

Barros, C. P., \& Leach, S. (2006b). Performance evaluation of the English Premier Football League with data envelopment analysis. Applied Economics, 38, 1449-1458.

Barros, C. P., \& Leach, S. (2007). Technical efficiency in the English Football Association Premier League with a stochastic cost frontier. Applied Economics Letters, 14, 731-741.

Budzinski, O. (2014). The competition economics of financial fair play. Ilmenau Economics Discussion Papers, No.85. Retrieved from http://papers.ssrn.com/abstract=2409632

Budzinski, O. (2018). Competition Policy in Sports Markets. In Sage Handbook of Sports Economics. Thousand Oaks, CA: Sage.

Budzinski, O., \& Müller, A. (2013). Finanzregulierung und internationale Wettbewerbsfähigkeit: Der Fall Deutsche Bundesliga. In R. Dewenter, J. Haucap, \& C. Kehder (Eds.), Wettbewerb und Regulierung in Medien (pp. 261-290). Politik und Märkten, Baden-Baden: Nomos.

Budzinski, O., \& Szymanski, S. (2015). Are Restrictions of Competition by Sports Associations Horizontal or Vertical in Nature? Journal of Competition Law \& Economics, 11, 409-429.

Carmichael, F., McHale, I., \& Thomas, D. (2011). Maintaining market position: Team performance, revenue and wage expenditure in the English Premier League. Bulletin of 
Economic Research, 63, 464-479.

Carmichael, F., \& Thomas, D. (2014). Team performance: production and efficiency in football. In J. Goddard \& P. Sloane (Eds.), Handbook on the Economics of Professional Football (pp. 143-165). Cheltenham: Edward Elgar.

Dawson, P., Dobson, S., \& Gerrard, B. (2000a). Estimating coaching efficiency in professional team sports: Evidence from English Association Football. Scottish Journal of Political Economy, 47, 399-421.

Dawson, P., Dobson, S., \& Gerrard, B. (2000b). Stochastic frontiers and the temporal structure of managerial efficiency in English soccer. Journal of Sports Economics, 1, 341-362.

Dobson, S. M., \& Goddard, J. A. (1998). Performance and revenue in professional league football: evidence from Granger causality tests. Applied Economics, 30, 1641-1651.

Eskelinen, J., \& Kuosmanen, T. (2013). Intertemporal efficiency analysis of sales teams of a bank: Stochastic semi-nonparametric approach. Journal of Banking \& Finance, 37, 51635175.

Färe, R., \& Primont, D. (2012). Multi-output production and duality: theory and applications. Amsterdam: Springer Netherlands.

Franck, E. (2014). Financial fair play in European club football: What is it all about? International Journal of Sports Finance, 9, 193-217.

Franck, E., \& Lang, M. (2014). A Theoretical Analysis of the Influence of Money Injections on Risk Taking in Football Clubs. Scottish Journal of Political Economy, 61, 430-454.

Garcia-del-Barrio, P., \& Szymanski, S. (2009). Goal! Profit maximization versus Win maximization in soccer. Review of Industrial Organization, 34, 45-68. 
Gerrard, B. (2005). A resource-utilization model of organizational efficiency in professional sports teams. Journal of Sport Management, 19, 143-169.

Glass, J. C., McKillop, D. G., \& Rasaratnam, S. (2010). Irish credit unions: Investigating performance determinants and the opportunity cost of regulatory compliance. Journal of Banking \& Finance, 34, 67-76.

Goddard, J. (2014). The promotion and relegation system. In J. Goddard \& P. Sloane (Eds.), Handbook on the Economics of Professional Football (pp. 23-40). Cheltenham: Edward Elgar Publishing.

González-Gómez, F., Picazo-Tadeo, A. J., \& García-Rubio, M. A., (2011) The impact of a mid- season change of manager on sporting performance, Sport, Business and Management: An International Journal,1, 28-42.

Guzmán, I., \& Morrow, S. (2007). Measuring efficiency and productivity in professional football teams: evidence from the English Premier League. Central European Journal of Operations Research, 15, 309-328.

Haas, D. J. (2003). Productive efficiency of English football teams - a data envelopment analysis approach. Managerial and Decision Economics, 24, 403-410.

Hall, S., Szymanski, S., \& Zimbalist, A. S. (2002). Testing causality between team performance and payroll: The cases of major league baseball and English soccer. Journal of Sports Economics, 3, 149-168.

Hughes, M., Hughes, P. , Mellahi, K. \& Guermat, C. (2010), Short-term versus Long-term Impact of Managers: Evidence from the Football Industry. British Journal of Management, 21, 571-589. 
Johnson, A. L., \& Kuosmanen, T. (2012). One-stage and two-stage DEA estimation of the effects of contextual variables. European Journal of Operational Research, 220, 559570.

Kuosmanen, T., Cherchye, L., \& Sipiläinen, T. (2006). The law of one price in data envelopment analysis: Restricting weight flexibility across firms. European Journal of Operational Research, 170, 735-757.

Kuosmanen, T., \& Johnson, A. L. (2009). Data envelopment analysis as nonparametric leastsquares regression. Operations Research, 58, 149-160.

Kuosmanen, T., Johnson, A., \& Saastamoinen, A. (2015). Stochastic nonparametric approach to efficiency analysis: A unified framework. In Data Envelopment Analysis (pp. 191-244). New York: Springer US.

Leach, S., \& Szymanski, S. (2015). Making Money Out of Football. Scottish Journal of Political Economy, 62, 25-50.

Maxcy, J. G. (2014) The American View on Financial Fair Play. ESEA Conference Volume. Budzinski, O. and Feddersen, A. (Eds.) Oxford, UK: Peter Lang International Academic Publishers, 2014. Retrieved from https://ssrn.com/abstract=2405241

Merton, R. K. (1936). The Unanticipated Consequences of Purposive Social Action. American Sociological Review, 1, 894-904.

Müller, J. C., Lammert, J., \& Hovemann, G. (2012). The financial fair play regulations of UEFA: An adequate concept to ensure the long-term viability and sustainability of European club football? International Journal of Sports Finance, 7, 117-140.

Mundlak, Y. (1961). Empirical Production Function Free of Management Bias. Journal of 
Farm Economics, 43, 44-56.

Mundlak, Y., \& Hoch, I. (1965). Consequences of Alternative Specifications in Estimation of Cobb-Douglas Production Functions. Econometrica: Journal of the Econometric Society, $33,814-828$.

Murray, B. C. (1995). Measuring Oligopsony Power with Shadow Prices: U.S. Markets for Pulpwood and Sawlogs. The Review of Economics and Statistics, 77, 486-498.

Peeters, T., \& Szymanski, S. (2014). Financial fair play in European football. Economic Policy, 29, 343-390.

Peltzman, S. (1976). Toward a More General Theory of Regulation. The Journal of Law and Economics, 19, 211-240.

Posner, R. A. (1974). Theories of Economic Regulation. The Bell Journal of Economics and Management Science, 5, 335.

Rumelt, R. P. (1991). How much does industry matter? Strategic Management Journal, 12, $167-185$.

Sass, M. (2016). Glory Hunters, Sugar Daddies, and Long-Term Competitive Balance Under UEFA Financial Fair Play. Journal of Sports Economics, 17(2), 148-158.

Spatt, C. S. (2006, March 17). Financial Regulation: Economic Margins and Unintended Consequences. Retrieved from https://www.sec.gov/news/speech/spch031706css.htm

Stigler, G. J. (1971). The Theory of Economic Regulation. The Bell Journal of Economics and Management Science, 2, 3-21.

Szymanski, S. (2014). Fair is Foul: A Critical Analysis of UEFA Financial Fair Play. International Journal of Sports Finance, 9, 218-229. 
Szymanski, S., \& Smith, R. (1997). The English Football Industry: profit, performance and industrial structure. International Review of Applied Economics, 11, 135-153.

Tulkens, H., \& Vanden Eeckaut, P. (1995). Non-parametric efficiency, progress and regress measures for panel data: Methodological aspects. European Journal of Operational Research, 80, 474-499.

Simar, L., \& Wilson, P. W. (2007). Estimation and inference in two-stage, semi-parametric models of production processes. Journal of Econometrics, 136, 31-64.

Tullock, G. (1980). Efficient Rent Seeking. In J. M. Buchanan, R. D. Tollison, \& G. Tullock (Eds.), Toward a theory of the rent-seeking society. College Station: Texas A \& M University Press.

Wernerfelt, B. (1984). A resource-based view of the firm. Strategic Management Journal, 5, $171-180$.

Vöpel, H. (2011). Do We Really Need Financial Fair Play in European Club Football? An Economic Analysis. CESifo DICE Report, 9(3), 54-60. 


\section{Tables}

TABLE 1

Financial Fair Play Loss Thresholds

\begin{tabular}{llll}
\hline Regulator & $\begin{array}{l}\text { Cumulative } \\
\text { Regular } \\
\text { Allowable Loss }\end{array}$ & $\begin{array}{l}\text { Cumulative } \\
\text { Maximum } \\
\text { Allowable Loss }\end{array}$ & Assessment Period \\
\hline UEFA & $€ 5 \mathrm{~m}$ & $€ 30 \mathrm{~m}$ & 3 rolling seasons \\
The Premier League & $£ 15 \mathrm{~m}$ & $£ 105 \mathrm{~m}$ & 3 rolling seasons \\
The Championship & $£ 15 \mathrm{~m}$ & $£ 39 \mathrm{~m}$ & 3 rolling seasons \\
\hline
\end{tabular}


TABLE 2

Variable Definitions

\begin{tabular}{|c|c|}
\hline Variable & Definition \\
\hline CostShare & $\begin{array}{l}\text { Cost share of club by season by tier. Cost is measured as the total of } \\
\text { salaries, amortisation of player registrations and match day expenses }\end{array}$ \\
\hline RevShare & Revenue share of club by season by tier \\
\hline PtsShare & Points share of club by season by tier \\
\hline TalentShare & Net book value of player registrations share of club by season by tier \\
\hline BE15M_d & $\begin{array}{l}\text { Break-even constraint dummy variable. Value equals } 1 \text { if the average } \\
\text { losses calculated over a three-year period are greater than } £ 15 \text { million, } 0 \\
\text { otherwise. }\end{array}$ \\
\hline BE10M_d & $\begin{array}{l}\text { Break-even constraint dummy variable. Value equals } 1 \text { if the average } \\
\text { losses calculated over a three-year period are greater than } £ 10 \text { million, } 0 \\
\text { otherwise. }\end{array}$ \\
\hline BE5M_d & $\begin{array}{l}\text { Break-even constraint dummy variable. Value equals } 1 \text { if the average } \\
\text { losses calculated over a three-year period are greater than } £ 5 \text { million, } 0 \\
\text { otherwise. }\end{array}$ \\
\hline BE5M3s_d & $\begin{array}{l}\text { Break-even constraint dummy variable. This variable takes the value } 1 \\
\text { if the club's cumulative three-year losses are greater than } £ 5 \text { million } \\
\text { and } 0 \text { otherwise. }\end{array}$ \\
\hline Promotion & $\begin{array}{l}\text { A dummy variable taking the value of } 1 \text { if the club gets promoted at the } \\
\text { end of that season and } 0 \text { otherwise. }\end{array}$ \\
\hline Relegated & $\begin{array}{l}\text { A dummy variable taking the value of } 1 \text { if the club was relegated at the } \\
\text { end of the prior season and } 0 \text { otherwise. }\end{array}$ \\
\hline $\mathrm{CL}$ & $\begin{array}{l}\text { A dummy variable taking the value of } 1 \text { if the club competed in the } \\
\text { Champions League in that season, } 0 \text { otherwise }\end{array}$ \\
\hline EL & $\begin{array}{l}\text { A dummy variable taking the value of } 1 \text { if the club competed in the } \\
\text { Europa League in that season, } 0 \text { otherwise }\end{array}$ \\
\hline $\begin{array}{l}\text { Commercial } \\
\text { Independence }\end{array}$ & $\begin{array}{l}\text { Revenue excluding central distributions from the domestic league and } \\
\text { European competitions as a percentage of total revenue. }\end{array}$ \\
\hline Stadium Utility & $\begin{array}{l}\text { Average attendance for the season as a percentage of the stadium } \\
\text { capacity. }\end{array}$ \\
\hline Manager Change & $\begin{array}{l}\text { A dummy variable taking the value one when there was a managerial } \\
\text { change in that season, zero otherwise. }\end{array}$ \\
\hline
\end{tabular}


TABLE 3

Panel A: Summary Statistics for Financial Data

\begin{tabular}{|c|c|c|c|c|c|c|c|}
\hline \multirow[b]{2}{*}{ Season End } & \multicolumn{5}{|c|}{ Revenue(£000) } & \multirow[b]{2}{*}{ Max } & \multirow[b]{2}{*}{ Count } \\
\hline & League & Mean & Median & StdDev & Min & & \\
\hline $2003-2004$ & Premier & 64,769 & 48,763 & 40,793 & 13,928 & 171,500 & 19 \\
\hline $2007-2008$ & Premier & 95,863 & 71,594 & 63,470 & 43,455 & 257,116 & 20 \\
\hline 2011-2012 & Premier & 117,004 & 78,638 & 81,163 & 52,597 & 320,320 & 20 \\
\hline $2016-2017$ & Premier & 228,810 & 156,975 & 140,064 & 116,927 & 581,204 & 20 \\
\hline $2003-2004$ & Championship & 13,756 & 9,018 & 11,263 & 4,119 & 39,633 & 23 \\
\hline $2007-2008$ & Championship & 14,026 & 12,146 & 7,104 & 4,786 & 32,648 & 24 \\
\hline $2011-2012$ & Championship & 20,005 & 17,760 & 9,918 & 8,279 & 46,899 & 22 \\
\hline $2016-2017$ & Championship & 30,776 & 23,752 & 20,705 & 11,486 & 85,685 & 23 \\
\hline \multicolumn{8}{|c|}{ Costs(£000) } \\
\hline 2003-2004 & Premier & 53,407 & 44,514 & 36,934 & 13,255 & 170,716 & 19 \\
\hline $2007-2008$ & Premier & 78,950 & 59,292 & 49,008 & 34,386 & 229,377 & 20 \\
\hline 2011-2012 & Premier & 106,160 & 76,468 & 69,341 & 39,732 & 284,820 & 20 \\
\hline $2016-2017$ & Premier & 169,957 & 134,308 & 97,696 & 83,548 & 385,875 & 20 \\
\hline $2003-2004$ & Championship & 10,418 & 8,376 & 7,689 & 2,542 & 28,489 & 23 \\
\hline $2007-2008$ & Championship & 14,389 & 13,808 & 7,511 & 3,521 & 31,539 & 24 \\
\hline $2011-2012$ & Championship & 21,067 & 20,311 & 10,608 & 6,153 & 51,419 & 22 \\
\hline 2016-2017 & Championship & 37,505 & 30,563 & 30,499 & 1,251 & 147,940 & 23 \\
\hline \multicolumn{8}{|c|}{ Net Book Value of Player Registrations (£000) } \\
\hline $2003-2004$ & Premier & 28,569 & 17,754 & 36,088 & 783 & 153,236 & 19 \\
\hline $2007-2008$ & Premier & 49,526 & 39,560 & 39,304 & 8,880 & 154,691 & 20 \\
\hline 2011-2012 & Premier & 56,617 & 25,691 & 64,257 & 5,472 & 226,244 & 20 \\
\hline 2016-2017 & Premier & 115,404 & 94,314 & 85,912 & 16,346 & 333,908 & 20 \\
\hline $2003-2004$ & Championship & 1,820 & 684 & 2,691 & 13 & 8,968 & 23 \\
\hline $2007-2008$ & Championship & 4,603 & 3,780 & 3,931 & 319 & 17,094 & 24 \\
\hline 2011-2012 & Championship & 4,314 & 2,400 & 5,248 & 192 & 17,924 & 22 \\
\hline $2016-2017$ & Championship & 18,272 & 9,321 & 24,246 & 398 & 93,500 & 23 \\
\hline
\end{tabular}


Panel B: Summary Statistics for Other Variables

Combined Across All Sample Years For Both Premier League and Championship Clubs

\begin{tabular}{ccccccc}
\hline Variable & Mean & Median & StdDev & Min & Max & Count \\
\hline BE15M_d & 0.18 & 0.00 & 0.38 & 0.00 & 1.00 & 594 \\
BE10M_d & 0.25 & 0.00 & 0.43 & 0.00 & 1.00 & 594 \\
BE5M_d & 0.44 & 0.00 & 0.50 & 0.00 & 1.00 & 594 \\
BE5M3s_d & 0.62 & 1.00 & 0.49 & 0.00 & 1.00 & 594 \\
Promotion & 0.06 & 0.00 & 0.24 & 0.00 & 1.00 & 594 \\
Relegated & 0.06 & 0.00 & 0.24 & 0.00 & 1.00 & 594 \\
CL & 0.10 & 0.00 & 0.30 & 0.00 & 1.00 & 594 \\
EL & 0.08 & 0.00 & 0.27 & 0.00 & 1.00 & 594 \\
Commercial Independence & 0.58 & 0.60 & 0.21 & 0.00 & 1.00 & 594 \\
Stadium Utility & 0.81 & 0.82 & 0.16 & 0.41 & 1.00 & 594 \\
Manager Change & 0.44 & 0.00 & 0.50 & 0.00 & 1.00 & 594 \\
\hline
\end{tabular}


TABLE 4

Descriptive Statistics of Cost Efficiency Scores by Regulatory Regime

\begin{tabular}{cccccc}
\hline Model & Mean & Std Dev & Median & Min & Max \\
\hline No FFP & 0.932 & 0.098 & 0.910 & 0.614 & 1 \\
BE15M & 0.891 & 0.111 & 0.841 & 0.588 & 1 \\
BE10M & 0.833 & 0.119 & 0.816 & 0.572 & 1 \\
BE5M & 0.763 & 0.131 & 0.699 & 0.499 & 1 \\
BE5M3s & 0.722 & 0.147 & 0.621 & 0.414 & 1 \\
\hline
\end{tabular}


TABLE 5

Comparative Efficiency Analysis of the Big 5 vs Other Clubs

\begin{tabular}{cccccc}
\hline Group & Model & Mean & Std Dev & $\begin{array}{c}\text { Wilcoxon Mann } \\
\text { Whitney rank sum } \\
\text { Z-test }\end{array}$ & $\begin{array}{c}\text { Efficiency Loss } \\
\text { relative to NoFFP } \\
\text { Model) }\end{array}$ \\
\hline Big5 & NoFFP & 0.9650 & 0.0900 & $1.70^{*}$ & \\
Others & & 0.8810 & 0.1110 & & \\
Big5 & BE15M & 0.9210 & 0.0770 & $2.21^{* *}$ & $4.40 \%$ \\
Others & & 0.8010 & 0.0608 & & $8.00 \%$ \\
Big5 & BE10M & 0.9210 & 0.1082 & $2.00^{* *}$ & $4.40 \%$ \\
Others & & 0.7350 & 0.0739 & & $14.60 \%$ \\
Big5 & BE5M & 0.9070 & 0.1124 & & $5.80 \%$ \\
Others & & 0.6212 & 0.0903 & $4.99^{* * *}$ & $25.98 \%$ \\
Big5 & BE5M3s & 0.8950 & 0.1295 & & $7.00 \%$ \\
Others & & 0.6010 & 0.1065 & & $7.77^{* * *}$ \\
\hline
\end{tabular}

Notes: $* * * \mathrm{p}<0.01 ; * * \mathrm{p}<0.05 ; * \mathrm{p}<0.10$. 
TABLE 6

Summary of StoNZED Shadow Prices

\begin{tabular}{ccccc}
\hline & \multicolumn{2}{c}{ Mean } & \multicolumn{2}{c}{ Median } \\
\hline Model & Revenue Share & Points Share & Revenue Share & Points Share \\
No FFP & 0.391 & 0.342 & 0.422 & 0.333 \\
BE15M & 0.416 & 0.315 & 0.429 & 0.310 \\
BE10M & 0.439 & 0.282 & 0.451 & 0.276 \\
BE5M & 0.491 & 0.259 & 0.507 & 0.240 \\
BE5M3s & 0.511 & 0.221 & 0.537 & 0.201 \\
\hline
\end{tabular}

Notes: These estimates can be interpreted as the opportunity cost of the output that was sacrificed in pursuit of an increase in the other output 
TABLE 7

Group Comparison Tests for Shadow Prices

\begin{tabular}{cccc}
\hline Model & $\begin{array}{c}\text { Equality of Variance } \\
\text { F-test }\end{array}$ & $\begin{array}{c}\text { Wilcoxon Mann } \\
\text { Whitney rank sum z- } \\
\text { test }\end{array}$ & $\begin{array}{c}\text { Kolmogorov- } \\
\text { Smirnov equality of } \\
\text { distribution D-test }\end{array}$ \\
\hline BE15M & $421.12^{* * *}$ & $5.41^{* * *}$ & $0.89^{* * *}$ \\
BE10M & $321.14^{* * *}$ & $5.13^{* * *}$ & $1.37^{* * *}$ \\
BE5M & $511.91^{* * *}$ & $7.65^{* * *}$ & $1.56^{* * *}$ \\
BE5M3s & $444.21^{* * *}$ & $6.81^{* * *}$ & $1.44^{* * *}$ \\
\hline
\end{tabular}

Notes: ${ }^{* * *} \mathrm{p}<0.01 ;{ }^{* *} \mathrm{p}<0.05 ;{ }^{*} \mathrm{p}<0.10$ 
TABLE 8

Marginal Effects of Environmental Variables

\begin{tabular}{|c|c|c|c|c|c|}
\hline Model & No FFP & $B E 15 M$ & $B E 10 M$ & $B E 5 M$ & BE5MЗs \\
\hline Promotion Push & $1.03 \% * * *$ & $1.06 \% * * *$ & $1.31 \% * * *$ & $2.12 \% * *$ & $2.21 \% * * *$ \\
\hline Relegation & $-1.49 \% *$ & $-2.15 \% *$ & $-2.19 \% * *$ & $-2.98 \% *$ & $-3.51 \% *$ \\
\hline CL & $4.25 \% * * *$ & $4.37 \% * *$ & $4.99 \% * *$ & $5.16 \% * *$ & $5.16 \% * *$ \\
\hline EL & $1.51 \% *$ & $1.62 \%$ & $1.66 \%$ & $1.50 \% *$ & $1.51 \% *$ \\
\hline $\begin{array}{l}\text { Commercial } \\
\text { Independence }\end{array}$ & $-2.19 \% * *$ & $-2.89 \% * * *$ & $-3.11 \% * * *$ & $-3.14 \% * * *$ & $-3.42 \% * * *$ \\
\hline Stadium Utility & $-1.18 \% * * *$ & $-1.39 \% * * *$ & $-1.48 \% * * *$ & $-1.78 \% * * *$ & $-2.21 \% * * *$ \\
\hline Manager Change & $1.22 \% *$ & $1.79 \% * *$ & $1.91 \% * *$ & $1.71 \% * * *$ & $1.51 \% * * *$ \\
\hline Manager Change $(t-1)$ & $-0.66 \% * * *$ & $-0.88 \% * *$ & $-1.47 \% * * *$ & $-1.61 \% * *$ & $-1.96 \% * * *$ \\
\hline BE15M_d & & $5.21 \% * * *$ & & & \\
\hline BE10M_d & & & $6.11 \% * *$ & & \\
\hline BE5M_d & & & & $6.75 \% * * *$ & \\
\hline BE5M3s & & & & & $7.29 \% * *$ \\
\hline Observations & 594 & 594 & 594 & 594 & 594 \\
\hline Partial $\mathrm{R}^{2}$ & 0.981 & 0.991 & 0.994 & 0.994 & 0.993 \\
\hline
\end{tabular}

Notes: This table shows the marginal effects of the coefficients from the estimation of equation 3 transformed by exponentiating to provide direct economic interpretation. Season/Tier dummies are included on all models but excluded from table 8 for brevity $* * * p<0.01$; $* * p<0.05 ; * p<0.1$. 